\title{
Gender Wise Comparison of Flipped Classroom Strategy on the Performance of Prospective Teachers
}

\author{
Maksal Minaz \\ PhD Scholar Department of Education, \\ Northern University Nowshera, Pakistan. \\ Rabia Tabassum \\ Professor, Chairperson Department of Education, \\ Northern University Nowshera Pakistan. \\ Ayaz Ahmad \\ Assistant Professor Department of Education, \\ Northern University Nowshera, Pakistan.
}

\begin{abstract}
Flipped classroom make its liberty in the modern technological era to change the passive classroom learning environment in active ones. Flipped classroom is reverse type of classroom learning situation where students do more actively participation. It is a natural phenomenon that every individual of this world has different form one another. Individual differences take place in real classroom situations, and it is also a fact that males and females has different in nature, likes and dislikes, responsibilities and so on. Therefore, present study was aimed to compare the performance of male and female prospective teachers in two different classroom situations. Sample of 48 prospective teachers selected from one of the affiliated college of education in Khyber Pakhtunkhwa (Pakistan) was divided in two equal groups. Where experimental group consist 16 males and 08 female prospective teachers and the control group was consisted 14 females and 10 males. True experimental research design was used and data was collected through pre-test and post-test. The t-test and ANOVA were used for the purpose of data analysis. Data reveled that there was found no gender difference within the groups while the performance of experimental group male and female were outstanding than the performance of control group males and females. The males of experimental group were achieved higher mean scores than the male of control group likewise, female of experimental group were achieved higher scores than the scores of females of control group. Findings of the study are in the favor of flipped classroom strategy therefore, it is recommended that the flipped classroom strategy should be focused by the university teachers as well as policy makers in Pakistan.
\end{abstract}

Key words: Flipped classroom, Prospective teachers, passive classroom learning environment, performance

\section{INTRODUCTION}

Flipped classroom pedagogical approach where the conventional teaching is reversed; the teacher centered instruction change in to student centered instruction the focus of this learning is the student. In flipped learning the teacher assist and guide the students technically as needed. Flipped classroom, as the name suggests is a class where the learner learns outside the classroom and active engagement with collaborative learning take place during the class. The unclear and ambiguous concepts are understandable in the classroom by holding discussion, asking question, think pair and share and multiple activities to promote their learning capabilities Bergmann and Sams [1]. 
According to Halili \& Zainuddin [6] Flipped classroom have countless advantages and rapidly getting popularity throughout the World. There are many things to praise about the concept of the flipped classroom. With positive results from many teachers and school districts throughout the country, there is no denying the fact that the approach can (and has been) successful in certain cases. Students are able to approach the learning materials and take it in at their own momentum. By covering lecture material at home and from a video based platform, students can privately observe the material. This strategy allows them to come near the learning at their own tempo without agonize of peers noticing them moving slower or faster. Students can discontinue, take break, reverse, and make speedy and forward learning materials so, that they can examine learning in their own way. It is iterative and cyclic because students can always take benefit from flip teaching Sawarynski ; EDUCAUSE [12-3].

\section{LITERATURE REVIEW}

Bergmann and Sams [1] stressed that the flipped learning model established less lecturing and more activity in the classroom; group activity was usually conducted in the flipped classroom to build up an interactive and active learning. The learners have a great time to exchange and elaborate their ideas during the class discussion. There are two strapping elements of flipped classroom, using technology media as the instruction of learning while outside the class, and establishing interactive and communicative learning while inside the class Zappe, Leicht, Messner, Litzinger and Lee [14]. Therefore, both inside and outside class activities are very effective throughout student learning process.

The classroom learning environment is conducive and the participants engage in concept mapping, collaborative learning and discussions through communicative applications available on hand devices like smart phones Morrison [9].

Hussain, S., Minaz, M., Ahmad, N., and Idris, M [7] mentioned that two types of material help in the process of teaching and learning; first one is electronic materials and secondly printed script reading materials. In research study the effect of e-reading and printed document reading on students' comprehension and retention power concluded that the students comprehension and retention power were boosted up as a result of e-reading and printed materials.

Every teaching strategy has its own potentials and drawbacks to play role in successes or collapse flipped classroom have also some difficulties faced by the researchers and participants. In same manner a research study was conducted by Whillier and Lystad [14] to evaluate the effectiveness and level of satisfaction of flipped classroom in the intensive mode classroom from neuroanatomy. Partners were taken from session 2011 and 2013. For partners of 2013 the authors designed assessment criteria where seminars, presentations and midterm were unrealistic and quizzes were allocated $25 \%$ of the grade. For 2011 session the authors were conducted final term examination both the examinations have equal level of difficulty. Results of the study clearly mentioned that both the cohorts were achieved similar grades. The mode of self rated knowledge of flipped classroom were and regular intensive mode was $\mathrm{p}=.182$ and the overall satisfaction was with the course was $\mathrm{p}=.892$. Authors discussed different research studies showed significant results of flipped classroom and concluded that flipped classroom did not add value to the intensive mode of experience.

In spite the fact that flipped classroom showed significant results in multiple researches but authors also give the impression of being a deep look on difficulties of flipped classroom. Enfield [4] tinted the personal experience of the instructor that flipped classroom instructor needs more potentials he is busy all the time form the making of video lecture to final 
production of the strategy. It is time consuming so most of the time teachers spend to produce the video and extra efficiency to classroom activities and the generalization of active leering environment. During this strategy the teacher converted his role as facilitator substitute of a responsible teacher in classroom.

Researchers mentioned that students have not enough time to watch the videos and then feedback on time some students fail to follow this method of instruction in the field if medical education (Chen et. al, ; Reyna; Missildine et. al; and Whillier, \& Lystad, [2-11-8, 14].

Tang et.al [13] conducted a research study by taking total number of 95 ophthalmology education forth year students where fifty one respondents were male and forty four were female respondents. The students were instructed ocular trauma module of the course by using flipped classroom strategy. The 47 respondents of (control group) were provided the opportunity to attend the lecture and assigned homework activity by the instructor. Pretest and posttest were used to evaluate the results of the respondents. Results of the study illustrated that flipped classroom male and female were vigorously participated during flipped classroom strategy.

\section{Purpose of The study}

Modern technology influences all of the life style of the human beings and education is the major area where technology brought a revolutionary change. The classroom learning environment converted from passive situations to active learning environment therefore, the present study was designed to investigate gender wise comparison of flipped classroom strategy on the performance of prospective teachers.

\section{Objectives}

The objectives of the study were as follow:

1. To measure the differences between the performance of male and female prospective teachers in flipped classroom

2. To investigate the differences between the performance of male and female prospective teachers in non-flipped classroom/traditional classrooms

3. To compare gender-wise performance of the flipped classroom and non-flipped classroom in the subject of Educational Psychology

\section{Hypotheses of the study}

Based on the above objectives of the following research hypotheses were formulated;

1. There are no significant differences between the performance of male and female prospective teachers of flipped classroom

2. There are no significant differences between the performance of male and female prospective teachers in non-flipped classroom

3. There is no significant difference between the male of control group and male experimental group on post test.

4. There is no significant difference between the female of control group and female of experimental group on posttest.

\section{METHODOLOGY}

The study was designed to explore gender wise comparison of flipped classroom strategy on the performance of prospective teachers therefore Sample of 48 prospective teachers selected from Sir Syed College of Education Katlang, Mardan was divided in two equal groups. Where experimental group consist 16 males and 08 female prospective teachers and the control group was consisted 14 females and 10 males. 


\section{Research Design}

True experimental research design was used and data was collected through pretest and posttest. Symbolic representation of the research design as follow:

$$
\begin{gathered}
\mathrm{R}-\mathrm{E}=\mathrm{O}_{1} \mathrm{~T} \mathrm{O}_{2} \\
\mathrm{R}-\mathrm{C}=\mathrm{O}_{3}-\mathrm{O}_{4} \\
\mathrm{~d}_{\mathrm{RE}}=\mathrm{O}_{2}-\mathrm{O}_{1} \\
\mathrm{~d}_{\mathrm{RC}}=\mathrm{O}_{4}-\mathrm{O}_{3} \\
\mathrm{D}=\mathrm{d}_{\mathrm{RE}}-\mathrm{d}_{\mathrm{RC}}
\end{gathered}
$$

Where

$\mathrm{R}=$ Randomly selected

$\mathrm{E}=$ Experimental group

$\mathrm{C}=$ Control group

$\mathrm{O}=$ Observation or Measurement

$\mathrm{T}=$ The experimental treatment to which a group is exposed i.e. Independent variable

$\mathrm{d}_{\mathrm{RE}}=$ The difference between the scores on pretest and posttest for the experimental group

$\mathrm{d}_{\mathrm{RC}}=$ The difference between the scores on pretest and posttest for the control group

"This design is one of the most effective in minimizing the threats to experimental validity. At the conclusion of the experimental period the difference between the mean test scores of the experimental and control groups are subjected to a test of statistical significance, a t-test or an analysis of variance ANOVA Farooq, [5]".

\section{Sample}

Sample of forty eight prospective teachers were selected through paired random sampling technique and then divided in to two equal groups experimental and control group. Where $58.33 \%$ respondents of control group were consisting female and $41.66 \%$ males, while $33.33 \%$ females and 66.66 were male respondents of the experimental group.

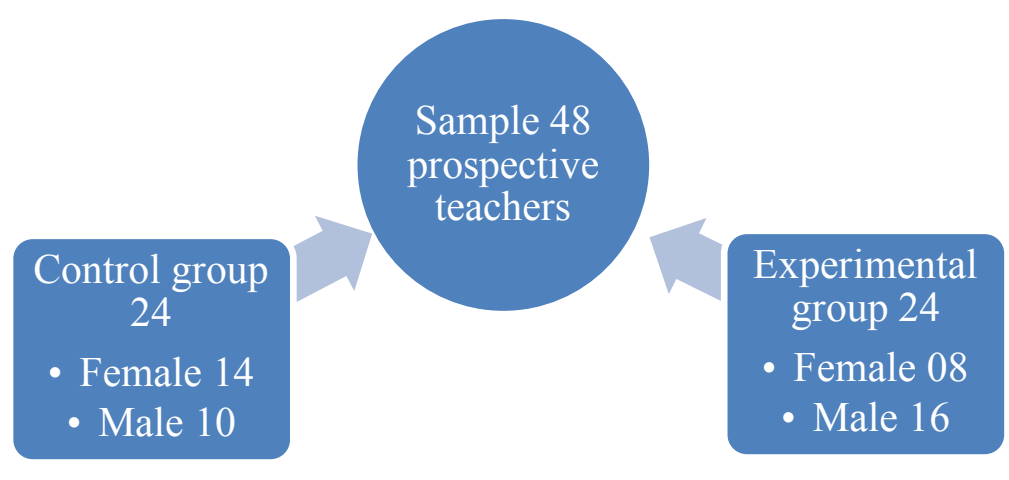

\section{Data Collection}

Pre-test and post-test was administered to collect the data from the participants of both groups. Both pretest and posttest was pilot tested. Pretest was administered to divide the sample students in to equal group on the basis of achieved mean scores likewise the post test was administered to compare the performance of both males and females sample prospective teachers after providing treatment of flipped classroom strategy.

\section{Validation and Reliability}

Researcher requested to the experts in the field of educational psychology to refine test items of both pre-test and post-test. Both pretest and post test were approved by the doctorial committee of the researcher. Assessment tests and flipped classroom strategy was pilot tested 
before starting the experiment. Therefore, twenty prospective teachers of Allama Iqbal Open University were preferred for the purpose of pilot test that they were not the part of the study. The reliability of the pilot pretest was determined by applying the Spearmen-Brown Prophecy formula where the correlation coefficient of the pretest was .80. The same pretest was administered as posttest after some sequential changes. Reliability was checked again and found the same 0.80 .

\section{Data Analysis}

Data was collected through pretest and posttest and was analyzed by $t$-test and ANOVA to compare the gender wise effect of flipped classroom strategy on the performance of prospective teachers.

\section{Procedure of treatment}

Subject of B.Ed curriculum (educational Psychology) were choose for the rationale of experiment. All 24 males and females prospective teachers of experimental group were taught through flipped classroom strategy for six academic weeks while a number of 24 male and female prospective teachers of control group were taught by conventional method for six academic weeks. Two different instructors were engaged to teach the both groups. The instructor of the experimental group was coped with additional teaching strategy (flipped classroom). Both males and females student teachers were provided the recorded flipped videos, power point presentation and soft copies of the learning material earlier to formal session. Flipped video was almost five to 10 minutes of duration. The instructor of the flipped classroom was confident that personal computer or any other technological devices are available with the student teacher to watch the flipped videos without any delay. The prospective teachers were given instructions by the instructor to watch the flipped videos and come to the class with clear concept. Class time was predetermined for active learning. The prospective teachers were engaged in discussion, concept mapping, presentation, think pair \& share to elucidate the unclear concepts.

\section{RESULTS}

Table 1

Frequency distribution of pre-test scores of male and female of experimental group

\begin{tabular}{lll}
\hline Class Intervals & $\begin{array}{l}\text { Frequencies of male of } \\
\text { Experimental group }\end{array}$ & $\begin{array}{l}\text { Frequencies of female of } \\
\text { Experimental group }\end{array}$ \\
$31-35$ & 0 & 0 \\
$26-30$ & 2 & 2 \\
$21-25$ & 6 & 2 \\
$16-20$ & 5 & 1 \\
$11-15$ & 3 & 3 \\
total & 16 & 8 \\
Mean scores & $\mathbf{1 9 . 6 9}$ & $\mathbf{2 0 . 2 5}$ \\
\hline
\end{tabular}

Table 1 shows that the mean scores of male and female prospective teachers of experimental groups were almost equal before treatment. Furthermore, range of the scores of male of experimental group was lies between 11 to 30 while the range of the scores of females of experimental group was lies between 13 to 29 which provide strong support to the results that male and female of experimental group was similar before treatment. Following table shows the mean and $t$ scores of the prospective teachers 
Table 2

Gender wise Comparison of the performance of experimental group male and female on pre-test

\begin{tabular}{lcccccc} 
RESPONDENTS & $\mathbf{N}$ & df & Mean & S.D & $\boldsymbol{t}$-value & Effect size \\
MALE & 16 & 22 & 19.69 & 4.80 & 0.13 & 0.09 \\
FEMALE & 08 & & 20.25 & 6.36 & & \\
\hline Not Significant & & & Table value at $0.05=1.717$ &
\end{tabular}

Table 2 shows that there is no significant difference between the mean scores $(\mathrm{N}=24)$ of male $(M=19.9, S D=4.8)$ and female $(M=20.25, S D=6.36)$ prospective teachers of experimental group on pre-test. The $t$ value $0.13 \geq .05$ is also support the difference of mean scores of both male and female. Therefore both male and female perform equally in pretest before treatment. Effect size is 0.09 very small indicated by Cohen'd value.

Table 3

Frequency distribution of pre-test scores of male and female of control group

\begin{tabular}{lll}
\hline Class Intervals & $\begin{array}{l}\text { Frequencies of male of control } \\
\text { group }\end{array}$ & $\begin{array}{l}\text { Frequencies of female of Control } \\
\text { group }\end{array}$ \\
$31-35$ & 1 & 0 \\
$26-30$ & 1 & 2 \\
$21-25$ & 5 & 2 \\
$16-20$ & 6 & 2 \\
$11-15$ & 1 & 3 \\
$6-10$ & 0 & 1 \\
Total students & 14 & 10 \\
Mean scores & $\mathbf{2 0 . 6}$ & $\mathbf{1 8 . 9}$
\end{tabular}

Table 3 shows that the mean scores of female prospective teachers of experimental groups and control group were almost equal before the treatment. Furthermore, range of the scores of experimental group was lies between 13 to 31 while the range of the scores of female of control group were lies between 10 to 29, support that both scores were identical. Which provide strong support to the results that male and female of both groups were same earlier than treatment.

Table 4

Gender wise comparison of the performance of control group male and female on pre-test

\begin{tabular}{lcccccc} 
RESPONDENTS & $\mathbf{N}$ & $\mathbf{d f}$ & Mean & S.D & $\boldsymbol{t}$-value & Effect size \\
MALE & 14 & & 20.6 & 4.79 & 0.43 & 0.7 \\
FEMALE & 10 & 22 & & 18.9 & 6.03 & \\
\hline Not significant & & & \multicolumn{3}{c}{ Table value at $0.05=1.717$}
\end{tabular}

The above table 4 shows that there is no significant difference between the mean scores $(\mathrm{N}=24)$ of male $(\mathrm{M}=20.06, \mathrm{SD}=4.79)$ and female $(\mathrm{M}=18.9, \mathrm{SD}=6.03)$ prospective teachers of control group on pre-test. The $t$ value $0.43 \geq .05$ is do not support the difference of mean scores of both male and female. Therefore both male and female perform equally in pretest before treatment. Effect size is 0.7 very small indicated by Cohen'd value. 
Table 5

ANOVA showing significant difference between the mean scores of prospective teachers of both groups on pre-test

\begin{tabular}{|c|c|c|c|c|c|}
\hline \multirow{3}{*}{$\begin{array}{l}\text { VARIABLES } \\
\text { Between Groups }\end{array}$} & \multirow{3}{*}{$\begin{array}{l}\text { Sum of Squares } \\
19.43\end{array}$} & \multirow{3}{*}{$\begin{array}{l}\text { df } \\
3\end{array}$} & \multirow{2}{*}{\multicolumn{2}{|c|}{ Mean Square F }} & \multirow[t]{3}{*}{ Effect size } \\
\hline & & & & & \\
\hline & & & 6.476 & \multirow{3}{*}{0.22} & \\
\hline Within Groups & 1259.04 & 44 & 28.614 & & \multirow[t]{2}{*}{0.01} \\
\hline Total & 1278.34 & 47 & & & \\
\hline
\end{tabular}

The above table 5 indicates that the $f$-value was found to be 0.22 which was less than the table F-value at 0.05 level of significance. Therefore, the null hypothesis was accepted. Effect size was found to be 0.01 .

Table 6

Gender wise Comparison of the performance of total male and female prospective teachers on post-test

\begin{tabular}{lcccccc}
\hline RESPONDENTS & $\mathbf{N}$ & df & Mean & S.D & $\boldsymbol{t}$-value & Effect size \\
MALE & 30 & & 28.70 & 4.45 & 0.002 & 0.00 \\
FEMALE & 18 & & 28.67 & 3.84 & & \\
\hline Not Significant & & & Table value at $0.05=1.679$
\end{tabular}

Table 6 shows that there is no significant difference between the mean scores $(\mathrm{N}=48)$ of male $(\mathrm{M}=28.07, \mathrm{SD}=4.45)$ and female $(\mathrm{M}=28.67, \mathrm{SD}=3.84)$ prospective teachers of on pre-test. The $t$ value $0.02 \geq .05$ is do not support the difference of mean scores of both male and female. Therefore both male and female performed equally in pretest. Effect size is 0.00 very small indicated by Cohen'd value.

Table 7

Gender wise comparison of the performance of experimental group male and female on posttest

\begin{tabular}{|c|c|c|c|c|c|c|}
\hline RESPONDENTS & $\mathbf{N}$ & df & Mean & S.D & $t$-value & Effect size \\
\hline MALE & 16 & 22 & 30.31 & 4.20 & 1.25 & 0.31 \\
\hline FEMALE & 08 & & 31.5 & 3.54 & & \\
\hline
\end{tabular}

Table 7 shows that there is no significant difference between the mean scores $(\mathrm{N}=24)$ of male $(\mathrm{M}=30.31, \mathrm{SD}=4.20)$ and female $(\mathrm{M}=31.5, \mathrm{SD}=3.54)$ prospective teachers of experimental group on post-test. The $t$ value $1.25 \geq .05$ is do not support the difference of mean scores of both male and female. Therefore performance both male and female was equally after treatment. There is no gender difference was found in experimental group. Effect size is 0.31 very small indicated by Cohen'd value. 
Table 8

Gender wise analysis of the performance of control group on post-test

\begin{tabular}{lllllll}
\hline RESPONDENTS & $\mathbf{N}$ & $\mathbf{d f}$ & Mean & $\mathbf{S . D}$ & $\boldsymbol{t}$-value & Effect size \\
MALE & 14 & & 26.86 & 4.11 & & \\
FEMALE & 10 & 22 & 26.4 & 2.31 & & 0.14 \\
\hline
\end{tabular}

Not Significant Table value at $0.05=1.717$

Table 8 shows that there is no significant difference between the mean scores $(\mathrm{N}=24)$ of male $(\mathrm{M}=26.06, \mathrm{SD}=4.11)$ and female $(\mathrm{M}=26.4, \mathrm{SD}=2.31)$ prospective teachers of control group on post-test. The $t$ value $0.14 \geq .05$ is do not support the difference of mean scores of both male and female. Therefore both male and female perform equally in posttest before treatment. However larger Standard deviation of male prospective teachers shows that there was variation among the students. Effect size is 0.13 very small indicated by Cohen'd value.

Table 9

ANOVA showing significance of difference between the mean scores of male and female prospective teachers of both groups on post-test

\begin{tabular}{|c|c|c|c|c|c|}
\hline VARIABLES & Sum of Squares & df & Mean Square & $\mathbf{F}$ & Effect size \\
\hline Between Groups & 204.755 & 3 & 68.25 & & \\
\hline Within Groups & 621.557 & 44 & 14.13 & $4.830^{*}$ & 0.25 \\
\hline Total & 826.312 & 47 & & & \\
\hline
\end{tabular}

Table 9 indicates that the $f$-value was found to be 4.830 which was greater than the table $\mathrm{F}$ value at 0.05 level of significance. The results support that the scores of experimental group male and female were higher than the mean scores of male and female of control group.

Table 10

Frequency distribution of post-test scores of female of experimental and control group

\begin{tabular}{lll}
\hline Class Intervals & $\begin{array}{l}\text { Frequencies of female of } \\
\text { Experimental group }\end{array}$ & $\begin{array}{l}\text { Frequencies of female of } \\
\text { Control group }\end{array}$ \\
$36-40$ & 1 & 0 \\
$31-35$ & 4 & 0 \\
$26-30$ & 3 & 6 \\
$21-25$ & 0 & 4 \\
$16-20$ & 0 & 0 \\
$11-15$ & 0 & 0 \\
Total students & 8 & 10 \\
Mean scores & $\mathbf{3 1 . 5 0}$ & $\mathbf{2 6 . 4 0}$ \\
\hline
\end{tabular}

Table 10 shows that the mean scores of female prospective teachers of experimental groups were higher after the treatment. Furthermore, range of the scores of experimental group was lies between 27 to 36 while the range of the scores of female of control group was fell between 22 to 30 . Which provide strong support to the results that female of experimental group was achieved high mean scores after treatment. 
Table 11

Gender wise comparison of the performance of experimental and control on post-test

\begin{tabular}{|c|c|c|c|c|c|c|}
\hline FEMALE & $\mathbf{N}$ & df & Mean & S.D & $t$-value & Effect size \\
\hline CONTROL & 10 & & 26.40 & 2.31 & & 1.70 \\
\hline EXPERIMENTAL & 08 & 16 & 31.50 & 3.55 & $2.48^{*}$ & \\
\hline
\end{tabular}

*Significant

Table value at $0.05=1.745$

Table 11 shows that there is no significant difference between the mean scores $(\mathrm{N}=24)$ of female control group $(M=26.40, S D=2.31)$ and female of experimental group $(M=31.50$, $\mathrm{SD}=3.55$ ) prospective teachers on post-test. The $t$-value $2.48 \geq .05$ also support the difference of mean scores of both female prospective teachers. Therefore both female prospective teachers of experimental group were achieved higher scores after teaching by flipped classroom strategy. Effect size is 1.70 high indicated by Cohen'd value.

Table 12

Frequency distribution of post-test scores of male of experimental and control group

\begin{tabular}{lll}
\hline Class Intervals & $\begin{array}{l}\text { Frequencies of male of } \\
\text { Experimental group }\end{array}$ & $\begin{array}{l}\text { Frequencies of male of } \\
\text { Control group }\end{array}$ \\
$36-40$ & 2 & 1 \\
$31-35$ & 5 & 1 \\
$26-30$ & 7 & 8 \\
$21-25$ & 2 & 3 \\
$16-20$ & 0 & 1 \\
$11-15$ & 0 & 0 \\
Total students & 16 & 14 \\
Mean scores & $\mathbf{3 0 . 3 1}$ & $\mathbf{2 6 . 8 6}$ \\
\hline
\end{tabular}

Table 12 shows that the male prospective teachers of experimental groups were achieved higher mean scores after the treatment. Furthermore, range of the scores of experimental group was lies between 24 to 37 while the range of the scores of control group was between 19 to 36. The results provide strong evidence that high mean scores of male of experimental group were due to flip classroom strategy.

Table 13

Gender wise comparison of the performance of experimental male and control group male on post-test

\begin{tabular}{lcccccc}
\hline MALE & $\mathbf{N}$ & $\mathbf{d f}$ & Mean & S.D & $\boldsymbol{t}$-value & Effect size \\
CONTROL & 14 & & 26.86 & 4.11 & & 0.83 \\
EXPERIMENTAL & 16 & 28 & & 30.31 & 4.21 & \\
\hline
\end{tabular}

*Significant

Table value at $0.05=1.701$

Table 13 shows that there is no significant difference between the mean scores $(\mathrm{N}=24)$ of male $(M=26.86, S D=4.11)$ and female $(M=30.31, S D=4.21)$ prospective teachers of control group on posttest. The $t$ value $1.15 \geq .05$ support the difference of mean scores of both male. Therefore male prospective teachers of experimental group showed higher performance after treatment. Effect size is 0.83 indicated by Cohen'd value. 


\section{FINDINGS}

Results of the study illustrated that male and female prospective teachers were achieved equal mean scores in pretest of both control and experimental group. The similar results showed that both have same level of performance. The ability of male and female of both groups were same in the subject of educational psychology when they were not provided the supplementary strategy.

The results of the study illustrated that male and female prospective teachers of the experimental group were achieved higher mean scores in post-test. The male prospective teachers of experimental group were achieved mean scores of 30.31 and male of control group were of 26.86.

Likewise, females of experimental group achieved higher mean scores as compare to the females of control group after providing treatment. Female of control group achieved mean score of 26.40 on the other hand the females of experimental group achieved mean scores of 31.50 .

Results of the study revealed that the performance of male and female of experimental group were outstanding after teaching by flipped classroom strategy.

\section{CONCLUSIONS}

On the basis of findings it was concluded that there was found no gender difference with in the groups. It is concluded that male and female prospective teachers of experimental group achieved identical scores and the male and female of control group prospective teachers were achieved the similar scores. The difference was found when the experimental groups were given the treatment of flipped classroom strategy and the control group was taught through conventional method. The higher scores of male and female were due to flipped classroom strategy. Flipped classroom is getting popular among the college and university students and instructors. The strategy is creating ways for teachers to create low cost educational platforms where many tools can easily deploy inside and outside the classroom Plotnikoff [10].

\section{RECOMMENDATIONS}

On the basis of findings following recommendations are given;

Flipped classroom strategy ha positive effect on the performance of both male and female prospective teachers therefore it is recommended that flipped classroom strategy should be flowed by the professional teacher. The positive effect of flipped classroom strategy indicates that the policy makers and curriculum developer should take steps to promote the emerging strategy in teacher education institutions and curriculum in Pakistan.

\section{Refrences}

Bergmann, J., \& Sams, A. (2014). Flipping for Mastery. Educational Leadership, 71 (4), 24-29.

Chen, Y., Wang, Y., Kinshuk, \& Chen, N. S. (2014). Is FLIP Enough? Or Should We Use The Flipped Model Instead?. Computers \& Education, 79, 16-27. doi: 10.1016/j.compedu.2014.07.004.

EDUCAUSE, (2012). 7 things you should know about: Educause.edu/eli, eli7081. pdf.

Enfield J. (2013). Looking at the impact of the flipped classroom model of instruction on undergraduate multimedia students at CSUN. Tech Trends. November vol. 57, No. 6, pp. 14-27.

Farooq, R. A. (2001). Understanding Research in Education. University institute of Education and Research, University of Agriculture Arid, Rawalpindi Pakistan.

Halili, S. H., \& Zainuddin, Z. (2105). Flipping the classroom; what we know and what we don't know. The online Journal of Distance Education and e-learning, 3 (1), 15-22. 
Hussain, S., Minaz, M., Ahmad, N., \& Idris, M. (2016). The effect of e-reading and printed document reading on student's comprehension and retention power. J. Appl. Environ. Biol. Sci, 6 (2S) 165-170 Text Road Publication.

Missildine K, Fountain R, Summers L, Gosselin K. (2013). Flipping the classroom to improve student performance and satisfaction. J Nurs Educ. 2013; 52:597-599.

Morrison, D. (2016). Three trends that will influence learning and teaching in 2016. Retrieved on $8^{\text {th }}$ March, 2017 from https://onlinelearninginsights.wordpress.com/2016/01/10/three-trends-that-will-influence-learning-andteaching-in-2016/. AER Teaching.

Plotnikoff, D. (2013). Classes should do hands-on exercises before reading and video, Stanford researchers say. Stanford Report, (c) Stanford University. Stanford, California 94305. Copyright Complaints Trademark Notice. http://news.stanford.edu/news/2013/july/flipped-learning-model-071613.html.

Reyna, J., Davila, Y.C. \& Meier, P. (2016). Enhancing the flipped classroom experience with the aid of inclusive design. In Proceedings of EdMedia 2016--World Conference on Educational Media and Technology (pp. 1795-1807).

Vancouver, BC, Canada: Association for the Advancement of Computing in Education (AACE). Retrieved March $6^{\text {th }}$, 2018 from https://www.learntechlib.org/p/173190/.

Sawarynski, K. E., Eastwood, J. L., \& Lyer, N. (2016). An integrated flipped classroom model for medical education. FASEB J. 2013;27:517.1.

Tang, F., Chen, C. T., Zhu, Y., Zuo, C., Zhong, Y., Wang, N., Zou, Y., \& Liang, D. (2017). Comparison between flipped classroom and lecture-based classroom in ophthalmology clerkship. Journal of Medical Education Online_Vol. 22 (1). ISSN: (Print) 1087-2981 to link http://dx.doi.org/10.1080/10872981.2017.1395679.

Whillier, S., \& Lystad, P. R. (2015). No differences in grades or level of satisfaction in a flipped classroom for Neuroanatomy. Journal of Chiropractic Education: October 2015, Vol. 29, No. 2, pp. 127-133.

http://journalchiroed.com/doi/10.7899/JCE-14-28?code=bthl-site.

Zappe, S., Leicht, R., Messner, J., Litzinger, T., \& Lee, H. (2009). Flipping the Classroom to Explore Active Learning in a Large Undergraduate Course. Proceedings of the 2009 American Society for Engineering Education Annual Conference and Exhibition. 